Article

\title{
What Motivates Users to Keep Using Social Mobile Payments?
}

\author{
Dongyan Nan ${ }^{1}$, Yerin Kim ${ }^{2}$, Min Hyung Park ${ }^{2}$ and Jang Hyun Kim ${ }^{1,2, *(1)}$ \\ 1 Department of Interaction Science, Sungkyunkwan University, Seoul 03063, Korea; ndyzxy0926@skku.edu \\ 2 Department of Applied Artificial Intelligence, Sungkyunkwan University, Seoul 03063, Korea; \\ yerinee95@skku.edu (Y.K.); pminhyung12@skku.edu (M.H.P.) \\ * Correspondence: alohakim@skku.edu
}

Received: 19 July 2020; Accepted: 20 August 2020; Published: 24 August 2020

\begin{abstract}
Due to the rapid diffusion of social mobile payment (SMP), the current research explores the post-adoption behavior of SMP users. It proposes a research model to determine the core predictors of users' continuance intentions to use SMPs. Through the analysis of survey data from South Korea, it indicates that satisfaction strongly and positively affects users' continuance intentions. Moreover, satisfaction is influenced by perceived usefulness (PU), security, and enjoyment. Interestingly, although perceived ease of use (PEU) does not directly affect satisfaction, it can indirectly influence satisfaction via users' PU and perceived enjoyment. Furthermore, perceived ubiquity has strong effects on users' PU and PEU. The study also discusses meaningful implications, and provides suggestions for future studies.
\end{abstract}

Keywords: social mobile payment; technology acceptance; enjoyment; security; ubiquity; sustainable development

\section{Introduction}

With the rapid development of social network platforms and financial technology, social network platform-based mobile payment (i.e., social mobile payment) services have emerged and changed people's lives. Social mobile payment (SMP) is one of the key fintech services leading the transition to a "cashless society". The representative examples are as follows.

WeChat Pay, based on China's most prominent social networking platform (i.e., WeChat), occupied roughly 39.5\% of the Chinese mobile payment market in 2019 [1]. Additionally, the number of WeChat Pay users has surpassed 800 million [2], accounting for roughly $57 \%$ of the population in China. KakaoPay, built on KakaoTalk (one of the most widely utilized social network platform in South Korea [3]), provides a similar banking service using the social media application as its base. By linking the users' existing bank accounts with the KakaoTalk app, it provides a handy PayNow service. In addition, KakaoPay launched its own bank account service, called KakaoBank, which now has broadened to various investment options and surpassed \$17.7 billion in transactions during 2018, cementing itself as the sector leader in South Korea [4]. Moreover, the number of KakaoPay users was above 30 million in 2019 [5], accounting for more than $60 \%$ of the population in South Korea.

In line with this trend, several prior studies [6-8] have explored the predictors affecting users' adoption of SMPs. For example, based on the technology acceptance model (TAM), Lee et al. [6] constructed a model for KakaoPay use and demonstrated that both perceived usefulness (PU) and compatibility strongly influence users' intentions. While Lee et al. [6] uses the term "platform based mobile payment" to refer to KakaoPay, the current research uses the term SMP for more elaborate description. This is to emphasize the fact that SMP is based on social network platforms among various 
kinds of mobile platforms. Research conducted by Qu et al. [9] uses the same terminology based on this logic.

Prior studies on SMPs have only explored users' initial intentions, not their continuance intentions. In terms of the long-term and sustainable development of specific products or services, it is more meaningful to explore users' continuance intentions, rather than their initial intentions $[10,11]$. Thus, the current study attempts to investigate users' continuance intentions to use SMP.

The current research constructs a causal model based on TAM [12] and expectation-confirmation theory (ECT) [10]. ECT claims that users' satisfaction is the core factor increasing continuance intention. Moreover, in ECT and related studies [10,13,14], PU strongly influences user satisfaction. Thus, it may be an effective way to explore users' continuance intentions by combining ECT with TAM [11]. Further, with respect to fintech services, Humbani and Wiese [15] explained a high percentage of variance in continuance intention by utilizing a TAM and ECT-based model. Interestingly, although both TAM and ECT are prominent in the field of innovative products and services adoption, there are only a few studies [15] that have constructed a research model for fintech service continuance use on the basis of TAM and ECT.

To provide better understanding of SMP continuance use, the current research also adds perceived enjoyment, ubiquity, and security to the research model.

Perceived enjoyment is one of the key predictors in the specific services adoption area [16]. Davis et al. [17], Venkatesh [18], and Venkatesh et al. [19] have suggested that hedonic value-related factors (e.g., perceived enjoyment) should be considered in technology adoption. Additionally, prior user-oriented research has uncovered a notable connection between perceived enjoyment and satisfaction $[20,21]$. Furthermore, the enjoyment of users in the process of using certain services increases when they can use this service without much effort [22]. That is, perceived enjoyment can be enhanced by perceived ease of use (PEU). Interestingly, the role of perceived enjoyment has been rarely discussed in continued use of fintech services. Additionally, the relationship between perceived enjoyment and PEU has been rarely addressed in the fintech service area. Thus, adding the perceived enjoyment to the combination of TAM and ECT-based model is meaningful.

Several studies have suggested that the role of perceived security should be explored in fintech service adoption [23], because if users feel that certain fintech services are unsecure and may put their money and privacy at risk, they will refuse to use those services [24,25]. Compared with credit card companies and banks, SMP service providers do not have much experience in financial markets [6]. Thus, users may pay attention to whether the service provider can guarantee the security of this fintech service. Therefore, the current study adds the perceived security to the research model.

With respect to specific services adoption, perceived ubiquity is one of the core factors which can lead individuals to feel positive perceptions of specific services by providing time and place convenience [26]. Moreover, several studies have found that perceived ubiquity can notably influence TAM constructs (PU and PEU) [26-28]. The notable connection between ubiquity and PU is also supported by network externality theory. Network externality is the level of impact that a certain product or service can make on a user because others are using the same product or service [29]. According to network externality theory, the usefulness of a specific product or service can be enhanced when the number of other agents using them increases [29]. To be more specific, users' PU and intentions will be enhanced when they can use specific services in various online and offline stores [6,29-31]. Furthermore, there are rare studies exploring the effect of perceived ubiquity with respect to continued use of fintech services. Thus, this research utilizes perceived ubiquity as one of the key factors in the model. 


\section{Literature Review}

\subsection{Fintech and $S M P$}

Fintech is conceptualized as the convergence of information and communication technology (ICT) and financial services [6]. The rapid growth of the global fintech market is anticipated to reach a market value of approximately $\$ 305$ billion by 2025 [32]. According to a forecast in [32], the market is estimated to expand at a compound annual rate of about $22.17 \%$ over the period of 2020-2025 [32]. While the fintech industry covers a wide range of technologies and services, this research will focus on one of its main subsidiary fields, SMP. SMP is one of the key fintech services which is contributing to the rapid development stated above. It is true that the concept of fintech might be too broad to discuss in detail here. However, due to the flourishing trend of various payment services in the South Korean context, the proximity between the terms fintech and SMP is relatively closer than in other cultures.

SMP is described as a kind of payment method that utilizes mobile devices (e.g., smartphones) to pay or transfer money to another person or business via the social network platform. Despite their lack of experience in financial markets, SMP service providers successfully took off in the fintech services market based on the strength of social network platforms and the huge number of existing users [6]. Compared to the online banking services provided by the traditional banks, in which the users have to download separate applications for each bank, KakaoPay enables users to just link their bank accounts with KakaoTalk without having to download any new application. Additionally, SMPs such as KakaoPay enable users to attach cute emojis and congratulatory messages when transferring money to friends and acquaintances. These functions have received a lot of public attention. Based on these strengths, KakaoPay got investment from Alipay and initiated its payment service in 34,000 offline stores in 2017 [33].

With this trend, the following representative studies have explored users' perspectives on fintech services (e.g., SMP). Matemba and Li [8] demonstrated that both relative advantage and PEU play notable roles in increasing users' intention to use WeChat Pay by analyzing the valid data from 212 Africans. Liébana-Cabanillas et al. [34] confirmed that perceived risk, service quality, and effort expectancy all had notable effects on users' continuance intentions to utilize near-field communication (NFC) payments in public transportation by examining data from 180 respondents in Malaga, Spain. In the context of mobile banking, Hassan and Wood [35] examined data from 251 Egyptians, and verified that both PU and trust lead to stronger individual intentions. Khalilzadeh et al. [23] explored the key determinants influencing individuals' intentions to utilize NFC payment services in restaurants by examining data from 412 participants. With respect to peer-to-peer payment, Kalinic et al. [36] concluded that PU strongly predicted Spanish users' intentions on the basis of the results from 701 respondents. Susanto et al. [37] developed an ECT- based model for smartphone banking use. According to results from 301 Korean respondents, they demonstrated that confirmation, self-efficiency, and PU all had notable effects on users' continuance intentions. Shao et al. [38] explored the role of trust in increasing continuance intention by analyzing the data from 740 mobile payment users in China. Lin et al. [7] found that task-technology fit was positively and strongly related to Korean users' intentions to use KakaoPay by examining 441 valid questionnaires.

These studies indicated that exploring users' initial and continuance intentions to use fintech services is crucial to the diffusion and success of fintech services (e.g., SMP). As there are rare studies investigating SMP continuance use, this research attempts to examine the key variables affecting users' continuance intentions to use SMP. Specifically, the current research attempts to utilize ECT, TAM, enjoyment, security, and ubiquity to construct the model and investigate continuance intentions. To this end, the authors gathered survey-based data from KakaoPay users in South Korea and used structural equal modeling (SEM) to test the model. 


\subsection{User Satisfaction}

With respect to SMP, the current research conceptualizes users' perceived satisfaction as "the users' post-assessment on overall experience with SMP." [10]

ECT is one of the most prominent theories investigating users' post-adoption behavior towards innovative products and services. ECT argues that satisfaction is the core predictor of continuance intention [10,39]. In line with this argument, Zhou [40] verified that satisfaction increased users' continuance intentions to use fintech services by analyzing valid data from 195 Chinese participants. Studies have also demonstrated this connection with respect to smart wearable devices [11] and online learning services [13]. Thus, regarding SMP, this study hypothesizes that:

Hypothesis 1 (H1). Satisfaction will lead to stronger users' continuance intentions to use SMP.

\subsection{TAM}

The TAM is one of the most representative models in the innovative products and services adoption field [41]. Several prior studies have constructed TAM-based models that have explained a high percentage of the variance in users' intentions to utilize innovative services such as fintech [42-44]. Thus, the present study adds some TAM constructs (i.e., PU and PEU) to its research model.

\subsubsection{PU}

The TAM considers the term "PU" to be a key predictor. This study conceptualizes PU as "the level to which users feel that SMP is useful and helps them conduct payment transactions" $[45,46]$.

Bhattacherjee [10] argued that PU significantly increased users' satisfaction with information systems. With respect to fintech services, Susanto et al. [37] verified that PU induced greater satisfaction. Other areas of products and services have validated this relationship as well $[14,47]$. Thus, with respect to SMP, the authors hypothesize that:

Hypothesis 2 (H2). PU will lead to greater user satisfaction with SMP.

\subsubsection{PEU}

This study interprets PEU as "the level to which users feel that utilizing SMP does not require much effort". [12] Moreover, studies have verified the notable influence of PEU on satisfaction in the context of fintech services [48], smart wearable devices [11], and online learning services [13].

The TAM states that users perceive a specific technology as useful and beneficial when they can utilize it easefully [12]. Moreover, this relationship has been verified by prior studies on fintech services. Tan et al. [49] analyzed data from 156 participants and demonstrated that PEU led to greater PU of NFC mobile payment services. Hassan and Wood [35] identified a positive connection between PEU and PU across cultures and countries by examining survey-based data from Americans and Egyptians. Thus, this study hypothesizes that:

Hypothesis 3 (H3). PEU will lead to greater user satisfaction with SMP.

Hypothesis 4 (H4). PEU will lead to greater PU of SMP.

\subsection{Perceived Enjoyment (PE)}

The current research conceptualizes PE as "the level to which users perceive enjoyable when they are using SMP" [50]. Several earlier user-oriented studies have mentioned that the hedonic value of innovative services such as PE is a key predictor of users' behavior [11,16]. 
With respect to users' post-adoption behavior with innovative services, several studies have verified the notable influence of PE on satisfaction. For example, See-To et al. [51] demonstrated that PE can lead to greater satisfaction with mobile video application by analyzing data from 270 participants. In addition, Joo et al. [21] examined validated data from 137 digital textbook users and confirmed that PE had a positive relationship with user satisfaction.

Additionally, Van der Heijden [22] verified that PEU could positively affect PE, because users feel enjoyment when they perceive that using specific products and services does not require significant effort [52]. Abdullah et al. [53] established a notable connection between the PE and PEU of e-portfolios based on results from 242 undergraduate students in the United Kingdom. Agrebi and Jallais [54] demonstrated that PEU positively influenced PE with respect to mobile shopping by analyzing the data from 400 French participants. Thus, with respect to SMP, this study hypothesizes that:

Hypothesis 5 (H5). PE will lead to greater user satisfaction with SMP.

Hypothesis 6 (H6). PE will be positively influenced by PEU of SMP.

\subsection{Perceived Security (PS)}

With respect to SMP, PS is conceptualized as "the level of security that users feel about using SMP in terms of protecting their financial asset and privacy" $[23,55]$. Some prior research has mentioned that PS is a key variable when examining users' adoption of fintech services [23]. If users feel that certain fintech services are unsecure and may put their money and privacy at risk, they will refuse to adopt those services [24,25]. Several scholars have demonstrated a notable connection between PS and satisfaction. According to the results from 340 Korean users of e-commerce service, Kim et al. [56] demonstrated that PS had a notable influence on satisfaction. In the context of fintech, Gupta et al. [57] verified that PS is positively related to user satisfaction by analyzing online survey-based data from India. Accordingly, this study hypothesizes that:

Hypothesis 7 (H7). PS will lead to greater user satisfaction with SMP.

\subsection{Perceived Ubiquity (PUB)}

Choi [26] suggested that PUB should be considered when exploring user experience with certain services, because space and time convenience (i.e., service ubiquity) can induce positive perceptions from users about certain services. This research conceptualizes PUB as "the level to which users feel that they can utilize SMP anytime and anywhere". [26]

Several scholars have mentioned that PUB can lead users to perceive the utilitarian values (i.e., PEU and PU) of certain mobile services [26,28]. This connection has been verified in the mobile services field. Kim et al. [27] demonstrated a strong connection between PUB and PU based on SEM results from 503 participants in the United States. Tojib and Tsarenko [28] uncovered a notable influence of PUB on PEU by analyzing data from Australia. Choi [26] analyzed data from 379 Koreans, and concluded that both PU and PEU were greatly determined by PUB. Accordingly, with regard as SMP, this study hypothesizes that:

Hypothesis 8 (H8). PUB will lead to greater PU of SMP.

Hypothesis 9 (H9). PUB will lead to greater PEU of SMP. 


\section{Methods}

The survey items in the current study referred to several prior studies (see Appendix A). Specifically, the scales of TAM constructs (PU and PEU) were adapted from Davis [12]. The scales of PE and PS were taken from Oghuma et al. [14] and Roca et al. [58], respectively. Then, the scale of PUB was adapted from Choi [26]. The scale of satisfaction was taken from Delone and Mclean [59] and Gu et al. [60]. Finally, the present research adapted the scale of continuance intention from Davis [12], Roca et al. [61], and Mouakket et al. [62]. All the original items were modified to reflect the theme of SMP.

Given that South Korea is one of the representative countries in the SMP service field, this study conducted an online survey and gathered validated data from 205 Korean participants (96 men, 109 women) who identified themselves as KakaoPay users. The questionnaire was distributed online through a university bulletin page. The participants were mainly in the age group of 18 to 39, which accounted for $96.5 \%$ of the sample. Those who were in the age group of $40+$ were $3.5 \%$ of the participants in total. Such demographic factors of the sample can be meaningful, considering the fact that those people in the age group of 20s and 30s are the majority of the actual KakaoPay user base [63]. Every questionnaire item was measured by a 5-point Likert scale (from $1=$ "Strongly disagree" to $5=$ "Strongly agree") [64-66].

SEM and confirmatory factor analysis were utilized to test the research model.

\section{Results}

\subsection{Validity}

Guidelines from prior studies $[67,68]$ required values over 0.7 for Cronbach's alpha, factor loading, and composite reliability, and over 0.5 for average variance extracted (AVE). In addition, every square root value of AVE should exceed the inter-construct correlation values [69]. As presented in Tables 1 and 2, the research model satisfied each form of reliability and validity.

Table 1. Internal and convergent reliability.

\begin{tabular}{|c|c|c|c|c|c|}
\hline Constructs & Items & Cronbach's Alpha & Factor Loading & Average Variance Extracted & Composite Reliability \\
\hline \multirow{2}{*}{$\begin{array}{c}\text { Perceived } \\
\text { usefulness (PU) }\end{array}$} & PU1 & 0.812 & 0.773 & 0.598 & 0.817 \\
\hline & PU2 & & 0.758 & & \\
\hline \multirow{2}{*}{$\begin{array}{l}\text { Perceived ease of use } \\
\qquad(\mathrm{PEU})\end{array}$} & PEU1 & 0.878 & 0.792 & 0.714 & 0.882 \\
\hline & PEU2 & & 0.833 & & \\
\hline \multirow{2}{*}{$\begin{array}{c}\text { Perceived } \\
\text { security (PS) }\end{array}$} & PS1 & 0.834 & 0.915 & 0.727 & 0.841 \\
\hline & PS2 & & 0.785 & & \\
\hline \multirow{3}{*}{ Perceived enjoyment (PE) } & PE1 & 0.916 & 0.777 & 0.795 & 0.920 \\
\hline & PE2 & & 0.956 & & \\
\hline & PE3 & & 0.931 & & \\
\hline \multirow{2}{*}{ Satisfaction } & SA1 & 0.932 & 0.926 & 0.872 & 0.932 \\
\hline & SA2 & & 0.942 & & \\
\hline \multirow{3}{*}{ Continuance intention } & CIU1 & 0.940 & 0.947 & 0.839 & 0.940 \\
\hline & CIU2 & & 0.902 & & \\
\hline & CIU3 & & 0.898 & & \\
\hline
\end{tabular}


Table 2. Discriminant tests.

\begin{tabular}{lccccccc}
\hline & $\mathbf{1}$ & $\mathbf{2}$ & $\mathbf{3}$ & $\mathbf{4}$ & $\mathbf{5}$ & $\mathbf{6}$ & $\mathbf{7}$ \\
\hline 1. PU & 0.773 & & & & & & \\
2. PEU & 0.633 & 0.845 & & & & & \\
3. PS & 0.348 & 0.308 & 0.853 & & & & \\
4. PE & 0.542 & 0.619 & 0.156 & 0.892 & & & \\
5. PUB & 0.615 & 0.511 & 0.349 & 0.455 & 0.880 & & \\
6. Satisfaction & 0.742 & 0.653 & 0.479 & 0.552 & 0.567 & 0.934 & \\
7. Continuance intention & 0.718 & 0.653 & 0.416 & 0.460 & 0.557 & 0.798 & 0.916 \\
\hline
\end{tabular}

\subsection{Model Fit}

This study calculated the measurement and structural models' fit indices. Table 3 demonstrates that the research model generally satisfied the index guidelines from Hair et al. [70].

Table 3. Fit indices.

\begin{tabular}{cccc}
\hline Indices & Measurement Model & Structural Model & Recommendation \\
\hline Chi-square /df & 1.794 & 1.919 & $<3$ \\
Comparative fit indices & 0.969 & 0.961 & $>0.9$ \\
Normed fit indices & 0.933 & 0.922 & $>0.9$ \\
Root mean square error of approximation & 0.062 & 0.067 & $<0.08$ \\
Incremental fit indices & 0.969 & 0.961 & $>0.9$ \\
\hline
\end{tabular}

\subsection{Hypothesis Tests}

In view of the SEM results from Figure 1, the authors accepted eight of the hypotheses, and rejected one (H3). The research model explained $74.1 \%, 80.2 \%, 65.9 \%, 34.5 \%$, and $34.2 \%$ of the variance of continuance intention, satisfaction, PU, PEU, and PE, respectively.

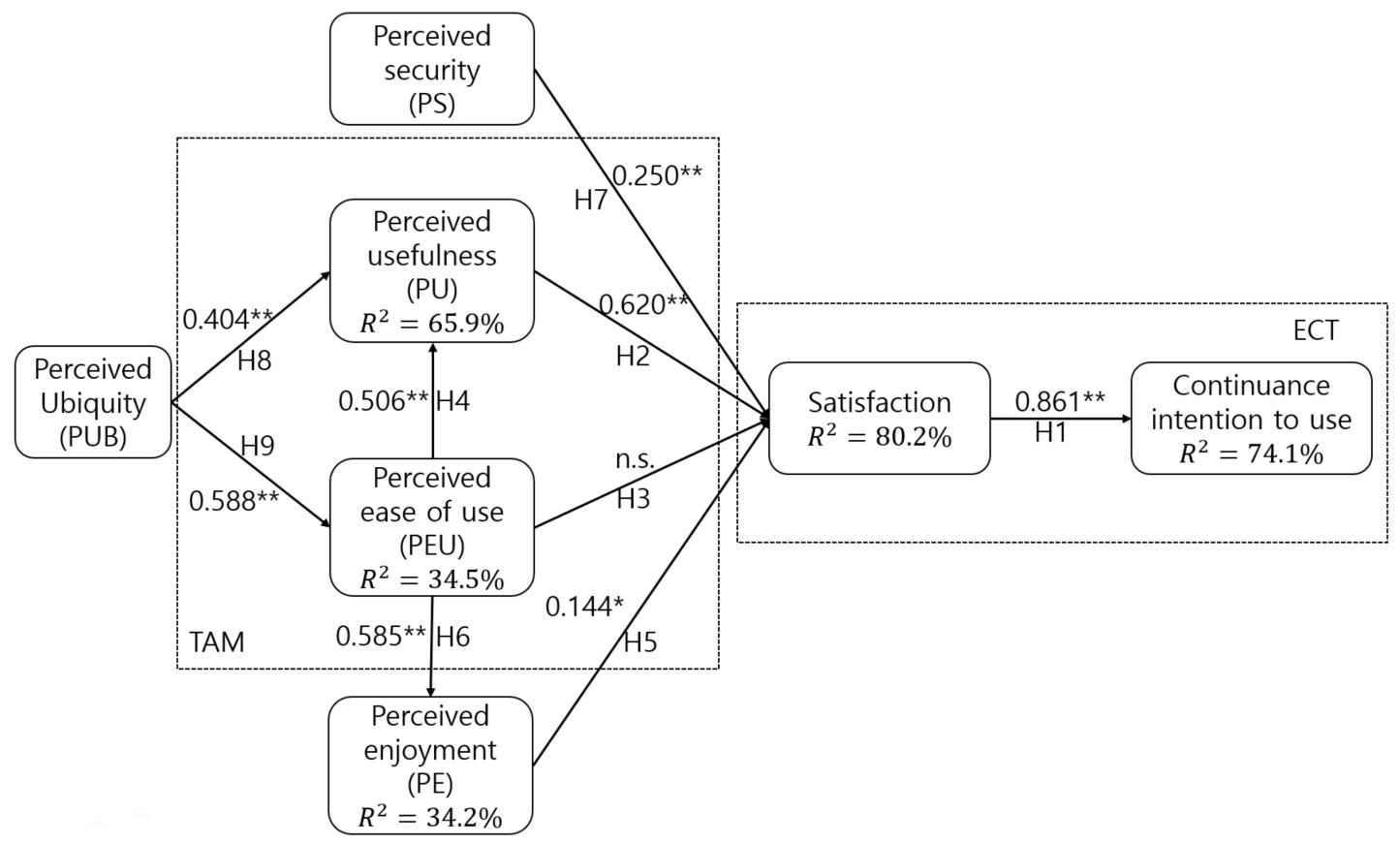

Figure 1. Summary of the results. Note. ${ }^{*}: p<0.01,{ }^{* *}: p<0.001$

Assessing $\mathrm{H} 1$, satisfaction strongly and significantly influenced continuance intention $(\mathrm{H} 1$, Beta $=0.861, \mathrm{CR}=16.611, \mathrm{SE}=0.060, p<0.001)$. In addition, $\mathrm{PU}(\mathrm{H} 2$, Beta $=0.620, \mathrm{CR}=6.709$, $\mathrm{SE}=0.107, p<0.001), \mathrm{PE}(\mathrm{H} 5$, Beta $=0.144, \mathrm{CR}=2.679, \mathrm{SE}=0.039, p<0.01)$, and PS (H7, Beta $=0.250$, 
$\mathrm{CR}=4.858, \mathrm{SE}=0.045, p<0.001)$ all positively and significantly affected satisfaction. However, there was no support for the connection between PEU and satisfaction.

Furthermore, PEU positively and significantly affected both $\mathrm{PU}(\mathrm{H} 4, \mathrm{Beta}=0.506, \mathrm{CR}=6.158$, $\mathrm{SE}=0.069, p<0.001)$ and PE $(\mathrm{H} 6$, Beta $=0.585, \mathrm{CR}=8.081, \mathrm{SE}=0.097, p<0.001)$. Lastly, PUB strongly and significantly determined both PU $(\mathrm{H} 8, \mathrm{Beta}=0.404, \mathrm{CR}=5.281, \mathrm{SE}=0.059, p<0.001)$ and PEU $(\mathrm{H} 9$, Beta $=0.588, \mathrm{CR}=7.669, \mathrm{SE}=0.071, p<0.001)$.

\subsection{Total Effects}

Table 4 reports the calculations for the total standardized effects of the antecedent determinants on continuance intention, with satisfaction having the strongest influence on continuance intention. In addition, both PU and PUB had strong indirect effects on continuance intention. Although there was no support for a connection between PEU and satisfaction, PEU had strong indirect effects on users' continuance intentions.

Table 4. Total effects on continuance intention.

\begin{tabular}{cccc}
\hline Factors & Direct Effect & Indirect Effect & Total Effect \\
\hline Perceived usefulness (PU) & - & 0.534 & 0.534 \\
Perceived ease of use (PEU) & - & 0.441 & 0.441 \\
Perceived security (PS) & - & 0.216 & 0.216 \\
Perceived enjoyment (PE) & - & 0.124 & 0.124 \\
Perceived ubiquity (PUB) & - & 0.475 & 0.475 \\
Satisfaction & 0.861 & - & 0.861 \\
\hline
\end{tabular}

\section{Discussion and Conclusions}

The current research is one of the first studies that explores the factors influencing users' continuance intentions to use SMP. Since prior research on SMP [6-8] only focused on users' initial intentions and not their continuance intentions, the contributions of the current research are noteworthy. The authors also provide several implications of SEM results.

\subsection{Theoretical Implications}

From an academic viewpoint, the current research demonstrates the effectiveness of a TAM and ECT-based model in explaining users' behavior towards SMP. The research model explained $80.2 \%$ and $74.1 \%$, respectively, of the variance in satisfaction and continuance intention. Thus, the explanatory power of the model is relatively high when compared to the results in Kumar et al. [71], Park [11], and other relevant studies. It means that constructing a research model by building on TAM, ECT, perceived security, enjoyment, and ubiquity is an effective way to investigate user behavior on SMP.

Additionally, the present research demonstrates the notable influence of perceived ubiquity on $\mathrm{PEU}$, as well as the strong influence of PEU on perceived enjoyment. Interestingly, the fintech service adoption field has rarely verified these relationships, so these findings can be considered as new contributions to the literature.

First, the authors uncovered a strong influence of satisfaction on continuance intention, while also demonstrating that PU positively influenced satisfaction. These findings indicate that users will be satisfied and keep utilizing a SMP service when they feel that this service is useful for them.

Second, the current research demonstrated the notable effect of perceived security on satisfaction. This means that user satisfaction with a SMP service will be increased when they feel that this service can keep their finances and privacy secured.

Third, a direct association between PEU and satisfaction was not found. This may be due to the users' familiarity with utilizing this SMP [72,73]. To further elaborate, SMP such as KakaoPay have already been improved for a long time to allow use of the services more effortlessly, and thus have established a user-friendly interface. Moreover, participants in this study, who were actual users of the 
service may be already capable of using this service skillfully. Therefore, they do not care much about whether the service is easy to use or not. That is, PEU may not be a significant factor compared to the users' first experience of using the service [73].

However, the present research found an indirect effect of PEU on satisfaction via PU and perceived enjoyment. These results imply that when the users put less effort into using SMP, they found that SMP service to be more useful. This also enhanced the sense of enjoyment coming from the service. These positive feelings then led to greater user satisfaction. To sum up, this study finds that when users are familiar with certain services (e.g., SMP), PEU may not directly influence user satisfaction, but it can indirectly affect satisfaction and continuance intention via other variables (e.g., perceived enjoyment, PU).

Fourth, perceived ubiquity strongly determined PEU and PU. This result reveals that users perceive a greater degree of utilitarian value (i.e., PU and PEU) when they feel that they can use SMP anytime and anywhere. Although the strong relationship between perceived ubiquity and PEU has been confirmed by several empirical studies (e.g., Choi [26]), it is rarely discussed in the fintech service adoption area. Thus, the present research suggests that this relationship should be considered when constructing a research model (e.g., TAM-based model) for fintech service. By doing this, the research model may provide a better understanding of fintech services adoption (e.g., SMPs, NFC mobile payments).

Fifth, although several prior studies have determined that hedonic value (e.g., perceived enjoyment) is a core factor in the long-term development of smart watches [11] and mobile video applications [51], the current research uncovered a relatively weak influence of perceived enjoyment on satisfaction and continuance intention. This means that, with respect to continued use of fintech services (e.g., SMP), users may tend to pay more attention to the utilitarian values and security of fintech services than their hedonic values.

\subsection{Practical Implications}

Based on the results of total effects (Table 4), this study suggests a guideline for service providers who wish to enhance their users' positive perspectives on their SMP services.

Service providers should primarily improve utilitarian values of their SMPs. Enhancing the ubiquity of SMP may be one of the most effective marketing strategies for leading users to perceive the utilitarian values of this service, and to continue their use of it. Thus, service providers should increase the number of places where users can use their SMP services, so that the users feel that they can utilize the service anytime and anywhere. For instance, applying services to public transportation fares is likely to create good outcomes. Furthermore, it is necessary to increase the number of online and offline stores available for SMP through cooperation between service providers and stores. Based on push-pull theory in the marketing context [74], making the service available at individual store level can enhance the audience awareness of the service and availability to meet existing needs. As a result, it can be another effective way to encourage users to use SMP.

Moreover, the security systems for SMPs need to be continually improved so that users will be satisfied with, and continue utilizing, SMPs. Compared to credit card companies and banks, SMP service providers do not have much experience in financial markets [6]. Thus, users may pay more attention to the security of financial assets rather than privacy. Therefore, service providers should focus on improving security systems for SMPs from the aspect of protecting financial assets.

Regarding the relatively weak influence of PE on continuance intention, it is likely that service providers do not need to make a lot of effort to enhance the hedonic values of their SMPs. Improving the utilitarian value of SMPs rather than the hedonic value may be more productive considering that the service providers' human and financial resources are limited.

\subsection{Limitations and Future Research}

The present study had some limitations, as following. 
Firstly, although Anderson and Gerbing [69] and Holbert and Stephenson [75] have reported that a sample size greater than 200 is sufficient to ensure the reliability and validity of structural modeling, the sample size $(\mathrm{N}=205)$ in this study can be considered relatively small, especially compared to the huge size of the South Korean SMP market. Therefore, future studies on SMP should utilize larger sample sizes to compensate for this limitation. Additionally, due to the fact that the questionnaires were distributed through the university bulletin web page, there is a high probability that a majority of the participants in this research were university students. In order to have access to broader user base, future research could consider other routes to assemble participants.

Secondly, a relative evaluation of SMP can contribute to a deeper analysis. For instance, Bounie et al. [76] showed that users' preference for certain payment services can differ depending on the evaluation method. The users reported a different level of preference for relative evaluation compared to absolute evaluation. Therefore, the authors suggest that future research can conduct a relative evaluation of SMP that compares KakaoPay with other mobile payments such as Apple Pay and Samsung Pay. Based on the findings of Bounie et al. [76], even if the new research measures the same factors that have been covered in the current research, the result could be different once the users are put in the situation of comparing different services. This would provide service providers with more meaningful and accurate practical implications.

Thirdly, while South Korea is a representative country in the SMP field, verifying our model in the context of other countries and cultures (e.g., China) is a meaningful avenue for further study.

Lastly, while both TAM and ECT are well known, there are other widely-used models in the technology adoption field (e.g., the unified theory of acceptance and use of technology (UTAUT) [77]). Therefore, it would be interesting to explore users' continuance intentions by utilizing a UTAUT-based model.

Author Contributions: Conceptualization, D.N. and J.H.K.; data curation, D.N; formal analysis, D.N. and M.H.P.; methodology, D.N.; project administration, J.H.K.; software, D.N.; supervision, J.H.K.; writing—original draft, D.N., Y.K.; writing-review \& editing, D.N., Y.K., M.H.P. and J.H.K. All authors have read and agreed to the published version of the manuscript.

Funding: This work was supported by a National Research Foundation of Korea (NRF) grant funded by the Korean government (NRF-2020R1A2C1014957).

Conflicts of Interest: The authors declare no conflict of interest.

\section{Appendix A}

Table A1. Composition of constructs in the model.

\begin{tabular}{|c|c|}
\hline Constructs & Items \\
\hline $\begin{array}{c}\text { Perceived } \\
\text { usefulness (PU) [12] }\end{array}$ & $\begin{array}{l}\text { 1. I think that KakaoPay is useful in my daily life. } \\
\text { 2. I think that KakaoPay is a useful mode of payment. } \\
\text { 3. KakaoPay helps me to conveniently conduct payment transactions. }\end{array}$ \\
\hline Perceived ease of use (PEU) [12] & $\begin{array}{l}\text { 1. Using KakaoPay does not require much effort. } \\
\text { 2. It is easy for me to become skillful at using KakaoPay. } \\
\text { 3. I think it is easy to interact with KakaoPay. }\end{array}$ \\
\hline $\begin{array}{c}\text { Perceived } \\
\text { enjoyment (PE) [14] }\end{array}$ & $\begin{array}{l}\text { 1. I enjoy using KakaoPay. } \\
\text { 2. Using KakaoPay gives me much enjoyment. } \\
\text { 3. Interacting with KakaoPay is fun. }\end{array}$ \\
\hline $\begin{array}{c}\text { Perceived } \\
\text { security (PS) [58] }\end{array}$ & $\begin{array}{l}\text { 1. KakaoPay can be protected against unauthorized access. } \\
\text { 2. Overall, I think KakaoPay is secure. }\end{array}$ \\
\hline $\begin{array}{c}\text { Perceived } \\
\text { ubiquity (PUB) [26] }\end{array}$ & $\begin{array}{l}\text { 1. I can use KakaoPay from anywhere. } \\
\text { 2. I can use KakaoPay at any time. } \\
\text { 3. I can use KakaoPay anytime and anywhere. }\end{array}$ \\
\hline
\end{tabular}


Table A1. Cont.

\begin{tabular}{cc}
\hline Constructs & Items \\
\hline Satisfaction $[59,60]$ & $\begin{array}{c}\text { 1. Overall, I am satisfied with KakaoPay. } \\
\text { 2. I am pleased with my experience of using KakaoPay. }\end{array}$ \\
\hline $\begin{array}{c}\text { Continuance } \\
\text { intention }[12,61,62]\end{array}$ & $\begin{array}{c}\text { 1. I intend to use KakaoPay. } \\
\text { will reuse KakaoPay in the future. }\end{array}$ \\
3. I intend to frequently use KakaoPay in the future.
\end{tabular}

\section{References}

1. China Banking News. China's Mobile Payments Market Grows Over 15\% in Q3 2019, Ali Pay's Market Share Exceed Half. 2020. Available online: http://www.chinabankingnews.com/2020/01/21/chinas-mobilepayments-market-grows-over-15-alipays-market-share-exceed-half/ (accessed on 5 May 2020).

2. Technode. WeChat Claims 1.08 Billion Users in Latest “One Minute” Data Report. 2018. Available online: https://technode.com/2018/11/19/wechat-1-minute-statistics-report/ (accessed on 5 May 2020).

3. Ha, Y.W.; Kim, J.; Libaque-Saenz, C.F.; Chang, Y.; Park, M.C. Use and gratifications of mobile SNSs: Facebook and KakaoTalk in Korea. Telemat. Inform. 2015, 32, 425-438. [CrossRef]

4. ZDnet. Kakao Pay Passes 20 Trillion Won Transaction Mark for 2018. 2019. Available online: https://www. zdnet.com/article/kakao-pay-passes-20-trillion-won-transaction-mark-for-2018/\#ftag=RSSbaffb68 (accessed on 23 March 2020).

5. The Korea Herald. Kakao Pay Starts Payment Service on Google Play, YouTube Premium. 2019. Available online: http://www.koreaherald.com/view.php?ud=20191211000561 (accessed on 8 March 2020).

6. Lee, J.; Ryu, M.H.; Lee, D. A study on the reciprocal relationship between user perception and retailer perception on platform-based mobile payment service. J. Retail. Consum. Serv. 2019, 48, 7-15. [CrossRef]

7. Lin, X.; Wu, R.; Lim, Y.T.; Han, J.; Chen, S.C. Understanding the Sustainable Usage Intention of Mobile Payment Technology in Korea: Cross-Countries Comparison of Chinese and Korean Users. Sustainability 2019, 11, 5532. [CrossRef]

8. Matemba, E.D.; Li, G. Consumers' willingness to adopt and use WeChat wallet: An empirical study in South Africa. Technol. Soc. 2018, 53, 55-68. [CrossRef]

9. Qu, Y.; Rong, W.; Chen, H.; Ouyang, Y.; Xiong, Z. Influencing factors analysis for a social network web based payment service in China. J. Theor. Appl. Electron. Commer. Res. 2018, 13, 99-113. [CrossRef]

10. Bhattacherjee, A. Understanding information systems continuance: An expectation-confirmation model. MIS Q. 2001, 25, 351-370. [CrossRef]

11. Park, E. User acceptance of smart wearable devices: An expectation-confirmation model approach. Telemat. Inform. 2020, 47, 101318. [CrossRef]

12. Davis, F.D. Perceived usefulness, perceived ease of use, and user acceptance of information technology. MIS Q. 1989, 13, 319-340. [CrossRef]

13. Joo, Y.J.; So, H.J.; Kim, N.H. Examination of relationships among students' self-determination, technology acceptance, satisfaction, and continuance intention to use K-MOOCs. Comput. Educ. 2018, 122, 260-272. [CrossRef]

14. Oghuma, A.P.; Libaque-Saenz, C.F.; Wong, S.F.; Chang, Y. An expectation-confirmation model of continuance intention to use mobile instant messaging. Telemat. Inform. 2016, 33, 34-47. [CrossRef]

15. Humbani, M.; Wiese, M. An integrated framework for the adoption and continuance intention to use mobile payment apps. Int. J. Bank Mark. 2019, 37, 646-664. [CrossRef]

16. Turel, O.; Serenko, A.; Bontis, N. User acceptance of hedonic digital artifacts: A theory of consumption values perspective. Inf. Manag. 2010, 47, 53-59. [CrossRef]

17. Davis, F.D.; Bagozzi, R.P.; Warshaw, P.R. Extrinsic and intrinsic motivation to use computers in the workplace 1. J. Appl. Soc. Psychol. 1992, 22, 1111-1132. [CrossRef]

18. Venkatesh, V. Determinants of perceived ease of use: Integrating perceived behavioral control, computer anxiety and enjoyment into the technology acceptance model. Inf. Syst. Res. 2000, 11, 342-365. [CrossRef]

19. Venkatesh, V.; Thong, J.Y.; Xu, X. Consumer acceptance and use of information technology: Extending the unified theory of acceptance and use of technology. MIS Q. 2012, 36, 157-178. [CrossRef] 
20. Thong, J.Y.; Hong, S.J.; Tam, K.Y. The effects of post-adoption beliefs on the expectation-confirmation model for information technology continuance. Int. J. Hum. Comput. Stud. 2006, 64, 799-810. [CrossRef]

21. Joo, Y.J.; Park, S.; Shin, E.K. Students' expectation, satisfaction, and continuance intention to use digital textbooks. Comput. Hum. Behav. 2017, 69, 83-90. [CrossRef]

22. Van der Heijden, H. User acceptance of hedonic information systems. MIS Q. 2004, 28, 695-704. [CrossRef]

23. Khalilzadeh, J.; Ozturk, A.B.; Bilgihan, A. Security-related factors in extended UTAUT model for NFC based mobile payment in the restaurant industry. Comput. Hum. Behav. 2017, 70, 460-474. [CrossRef]

24. Yi, J.; Yuan, G.; Yoo, C. The effect of the perceived risk on the adoption of the sharing economy in the tourism industry: The case of Airbnb. Inf. Process. Manag. 2020, 57, 102108. [CrossRef]

25. Li, K.; Cheng, L.; Teng, C.I. Voluntary sharing and mandatory provision: Private information disclosure on social networking sites. Inf. Process. Manag. 2020, 57, 102128. [CrossRef]

26. Choi, S. What promotes smartphone-based mobile commerce? Mobile-specific and self-service characteristics. Internet Res. 2018, 28, 105-122. [CrossRef]

27. Kim, S.; Baek, T.H.; Kim, Y.K.; Yoo, K. Factors affecting stickiness and word of mouth in mobile applications. J. Res. Interact. Mark. 2016, 10, 177-192. [CrossRef]

28. Tojib, D.; Tsarenko, Y. Post-adoption modeling of advanced mobile service use. J. Bus. Res. 2010, 65, 922-928. [CrossRef]

29. Van Hove, L. Electronic money and the network externalities theory: Lessons for real life. Netnomics 1999, 1, 137-171. [CrossRef]

30. Katz, M.L.; Shapiro, C. Network externalities, competition, and compatibility. Am. Econ. Rev. 1985, $75,424-440$.

31. Bounie, D.; François, A.; Van Hove, L. Consumer payment preferences, network externalities, and merchant card acceptance: An empirical investigation. Rev. Ind. Organ. 2017, 51, 257-290. [CrossRef]

32. Market Data Forecast. Global Fintech Market Research Report. 2020. Available online: https://www. marketdataforecast.com/market-reports/fintech-market (accessed on 22 April 2020).

33. Pulse Kakao Pay Teams up with Alipay on $\$ 200$ Million Partnership. 2017. Available online: https: //pulsenews.co.kr/view.php?year=2017\&no=125681 (accessed on 22 April 2020).

34. Liébana-Cabanillas, F.; Molinillo, S.; Ruiz-Montañez, M. To use or not to use, that is the question: Analysis of the determining factors for using NFC mobile payment systems in public transportation. Technol. Forecast. Soc. Chang. 2019, 139, 266-276. [CrossRef]

35. Hassan, H.E.; Wood, V.R. Does country culture influence consumers' perceptions toward mobile banking? A comparison between Egypt and the United States. Telemat. Inform. 2020, 46, 101312. [CrossRef]

36. Kalinic, Z.; Marinkovic, V.; Molinillo, S.; Liébana-Cabanillas, F. A multi-analytical approach to peer-to-peer mobile payment acceptance prediction. J. Retail. Consum. Serv. 2019, 49, 143-153. [CrossRef]

37. Susanto, A.; Chang, Y.; Ha, Y. Determinants of continuance intention to use the smartphone banking services. Ind. Manage. Data Syst. 2016, 116, 508-525. [CrossRef]

38. Shao, Z.; Zhang, L.; Li, X.; Guo, Y. Antecedents of trust and continuance intention in mobile payment platforms: The moderating effect of gender. Electron. Commer. Res. Appl. 2019, 33, 100823. [CrossRef]

39. Choi, M.; Han, K.; Choi, J. The effects of product attributes and service quality of transportation card solutions on service user's continuance and word-of-mouth intention. Serv. Bus. 2015, 9, 463-490. [CrossRef]

40. Zhou, T. An empirical examination of continuance intention of mobile payment services. Decis. Support Syst. 2013, 54, 1085-1091. [CrossRef]

41. Gibreel, O.; AlOtaibi, D.A.; Altmann, J. Social commerce development in emerging markets. Electron. Commer. Res. Appl. 2018, 27, 152-162. [CrossRef]

42. Abroud, A.; Choong, Y.V.; Muthaiyah, S.; Fie, D.Y.G. Adopting e-finance: Decomposing the technology acceptance model for investors. Serv. Bus. 2015, 9, 161-182. [CrossRef]

43. Kim, K.J.; Shin, D.H. An acceptance model for smart watches. Internet Res. 2015, 25, 527-541. [CrossRef]

44. Liébana-Cabanillas, F.; Sánchez-Fernández, J.; Muñoz-Leiva, F. The moderating effect of experience in the adoption of mobile payment tools in Virtual Social Networks: The m-Payment Acceptance Model in Virtual Social Networks (MPAM-VSN). Int. J. Inf. Manag. 2014, 34, 151-166. [CrossRef]

45. Phonthanukitithaworn, C.; Sellitto, C.; Fong, M.W. A comparative study of current and potential users of mobile payment services. Sage Open 2016, 6, 2158244016675397. [CrossRef] 
46. Verma, S.; Bhattacharyya, S.S.; Kumar, S. An extension of the technology acceptance model in the big data analytics system implementation environment. Inf. Process. Manag. 2018, 54, 791-806. [CrossRef]

47. Kim, K.; Hwang, J.; Zo, H.; Lee, H. Understanding users' continuance intention toward smartphone augmented reality applications. Inf. Dev. 2016, 32, 161-174. [CrossRef]

48. Chen, L.Y.; Wu, W.N. An exploration of the factors affecting users' satisfaction with mobile payments. Int. J. Comput. Sci. Inf. Technol. 2017, 9, 97-105.

49. Tan, G.W.H.; Ooi, K.B.; Chong, S.C.; Hew, T.S. NFC mobile credit card: The next frontier of mobile payment? Telemat. Inform. 2014, 31, 292-307. [CrossRef]

50. Ko, E.; Kim, E.Y.; Lee, E.K. Modeling consumer adoption of mobile shopping for fashion products in Korea. Psychol. Mark. 2009, 26, 669-687. [CrossRef]

51. See-To, E.W.; Papagiannidis, S.; Cho, V. User experience on mobile video appreciation: How to engross users and to enhance their enjoyment in watching mobile video clips. Technol. Forecast. Soc. Chang. 2012, 79, 1484-1494. [CrossRef]

52. Rodrigues, L.F.; Oliveira, A.; Costa, C.J. Does ease-of-use contributes to the perception of enjoyment? A case of gamification in e-banking. Comput. Hum. Behav. 2016, 61, 114-126. [CrossRef]

53. Abdullah, F.; Ward, R.; Ahmed, E. Investigating the influence of the most commonly used external variables of TAM on students' Perceived Ease of Use (PEOU) and Perceived Usefulness (PU) of e-portfolios. Comput. Hum. Behav. 2016, 63, 75-90. [CrossRef]

54. Agrebi, S.; Jallais, J. Explain the intention to use smartphones for mobile shopping. J. Retail. Consum. Serv. 2015, 22, 16-23. [CrossRef]

55. Shin, D.H. Towards an understanding of the consumer acceptance of mobile wallet. Comput. Hum. Behav. 2009, 25, 1343-1354. [CrossRef]

56. Kim, M.J.; Chung, N.; Lee, C.K. The effect of perceived trust on electronic commerce: Shopping online for tourism products and services in South Korea. Tour. Manag. 2011, 32, 256-265. [CrossRef]

57. Gupta, A.; Yousaf, A.; Mishra, A. How pre-adoption expectancies shape post-adoption continuance intentions: An extended expectation-confirmation model. Int. J. Inf. Manag. 2020, 52, 102094. [CrossRef]

58. Roca, J.C.; García, J.J.; De La Vega, J.J. The importance of perceived trust, security and privacy in online trading systems. Inf. Manag. Comput. Secur. 2009, 17, 96-113. [CrossRef]

59. Delone, W.H.; McLean, E.R. The DeLone and McLean model of information systems success: A ten-year update. J. Manag. Inform. Syst. 2003, 19, 9-30.

60. Gu, W.; Bao, P.; Hao, W.; Kim, J. Empirical examination of intention to continue to use smart home services. Sustainability 2019, 11, 5213. [CrossRef]

61. Roca, J.C.; Chiu, C.M.; Martínez, F.J. Understanding e-learning continuance intention: An extension of the Technology Acceptance Model. Int. J. Hum. Comput. Stud. 2006, 64, 683-696. [CrossRef]

62. Mouakket, S. Factors influencing continuance intention to use social network sites: The Facebook case. Comput. Hum. Behav. 2015, 53, 102-110. [CrossRef]

63. Financial Today. 2018. Available online: http://www.ftoday.co.kr/news/articleView.html?idxno=105185 (accessed on 18 March 2020).

64. Kim, H.J.; Jang, H.Y. Sustainable Technology Integration in Underserved Area Schools: The Impact of Perceived Student Change on Teacher Continuance Intention. Sustainability 2020, 12, 4802. [CrossRef]

65. Gbongli, K.; Xu, Y.; Amedjonekou, K.M. Extended Technology Acceptance Model to predict mobile-based money acceptance and sustainability: A multi-analytical structural equation modeling and neural network approach. Sustainability 2019, 11, 3639. [CrossRef]

66. Talom, F.S.G.; Tengeh, R.K. The Impact of Mobile Money on the Financial Performance of the SMEs in Douala, Cameroon. Sustainability 2020, 12, 183. [CrossRef]

67. Nunnally, J.C. Psychometric Theory, 2nd ed.; McGraw-Hill: New York, NY, USA, 1978.

68. Fornell, C.; Larcker, D.F. Evaluating structural equation models with unobservable variables and measurement error. J. Mark. Res. 1981, 18, 39-50. [CrossRef]

69. Anderson, J.C.; Gerbing, D.W. Structural equation modeling in practice: A review and recommended two-step approach. Psychol. Bull. 1998, 103, 411. [CrossRef]

70. Hair, J.; Black, W.; Babin, B.; Anderson, R. Multivariate Data Analysis, 7th ed.; Prentice-Hall, Inc.: Upper Saddle River, NJ, USA, 2010. 
71. Kumar, A.; Adlakaha, A.; Mukherjee, K. The effect of perceived security and grievance redressal on continuance intention to use M-wallets in a developing country. Int. J. Bank Mark. 2018, 36, 1170-1189. [CrossRef]

72. Oliveira, T.; Thomas, M.; Baptista, G.; Campos, F. Mobile payment: Understanding the determinants of customer adoption and intention to recommend the technology. Comput. Hum. Behav. 2016, 61, 404-414. [CrossRef]

73. Slade, E.L.; Dwivedi, Y.K.; Piercy, N.C.; Williams, M.D. Modeling consumers' adoption intentions of remote mobile payments in the United Kingdom: Extending UTAUT with innovativeness, risk, and trust. Psychol. Mark. 2015, 32, 860-873. [CrossRef]

74. Donnelly, J.J.H.; Peter, J.P. Preface to Marketing Management; McGraw-Hill: New York, NY, USA, 2012.

75. Holbert, R.L.; Stephenson, M.T. Structural equation modeling in the communication sciences, 1995-2000. Hum. Commun. Res. 2002, 28, 531-551.

76. Bounie, D.; François, A.; Van Hove, L. Merchant Acceptance of Payment Cards:"Must Take" or "Wanna Take"? Rev. Netw. Econ. 2016, 15, 117-146. [CrossRef]

77. Venkatesh, V.; Morris, M.G.; Davis, G.B.; Davis, F.D. User acceptance of information technology: Toward a unified view. MIS Q. 2003, 27, 425-478. [CrossRef]

(C) 2020 by the authors. Licensee MDPI, Basel, Switzerland. This article is an open access article distributed under the terms and conditions of the Creative Commons Attribution (CC BY) license (http://creativecommons.org/licenses/by/4.0/). 